\title{
GLACIER APPLICATIONS OF ERTS IMAGES
}

\author{
By R. M. Krimmel and M. F. Meier \\ (U.S. Geological Survey, Tacoma, Washington 98402 , U.S.A.)
}

Anstract. The ERTS satellite's sun-synchronous orbit covers the entire Earth from lat. $8 \mathbf{1}^{\circ} \mathbf{N}$. to $8 \mathrm{I}^{\circ} \mathrm{S}$. every $18 \mathrm{~d}$ at approximately 10.00 a.m. ground time. The scanners on board have continued to relay images to Earth from the launch on 23 July 1972 to the present (summer 1974). Images from four spectral bands $\left(0.5^{-1.1} \mathrm{\mu m}\right)$, with ground resolution of about $100 \mathrm{~m}$, cover an area $185 \mathrm{~km}$ on a side. The resulting images have proved to be very useful for collecting certain basic data from glaciers.

Long-term surface velocities are readily determined by comparison of recent ERTS images with maps that have been produced from earlier data. Images have been used to measure velocities on the Malaspina Glacier over a to year period, surge displacements on the Lowell, Tenas Tikke, and Tweedsmuir Glaciers and Lednik Medvezhiy, and velocity at the margin of the Hubbard Glacier. Many surging glaciers are readily identifiable on the images. Coverage from the satellite will allow surging glaciers to be identified world-wide which may help glaciologists to understand their peculiar geographical distribution. Images of large glaciers taken under conditions of low sun angle and complete snow cover show previously undetected subtle slope changes which can be interpreted as dynamic flow features or reflections of subglacial topography.

ERTS imagery is providing new glacier data for several reasons: very large areas are covered repetitively with sufficient consistency to show subtle tonal changes, conditions of maximum and minimum snow cover, subtle morphologic features at low sun angle, and changes in position of glaciers.

RÉsumÉ. Applications glaciologiques des images ERTS. L'orbite synchrone avec le soleil du satellite ERTS couvre la terre entière depuis la latitude $8 \mathrm{I}^{\circ} \mathrm{N}$. à $8 \mathrm{I}^{\circ} \mathrm{S}$. tous les $\mathrm{i} 8$ jours à environ $\mathrm{ro}$ heures du matin de l'heure au sol. Les capteurs "scanners" du bord ont continué de transmettre vers la terre depuis le lancement le 23 juillet 1972 jusqu'à maintenant (été $\mathrm{I} 974$ ). Les images dans 4 bandes du spectre $(0,5$ à $\mathrm{I}, \mathrm{I} \mu \mathrm{m})$ avec une résolution au sol d'environ $100 \mathrm{~m}$, couvrent une surface de $185 \mathrm{~km}$ de côté. Les images obtenues ont prouvé qu'elles étaient très utilisables pour recueillir certaines données de base sur les glaciers.

Des vitesses superficielles à long terme sont faciles à déterminer en comparant des images récentes d'ERTS avec des cartes rédigées à partir de données plus anciennes. On a utilisé ces images pour mesurer les vitesses du Malaspina Glacier sur une période de io ans, les déplacements rapides des glaciers en crue du Lowell Glacier, de Tenas Tikke Glacier, du Tweedsmuir Glacier et du Lednik Medvezhiy, et la vitesse latérale du Hubbard Glacier. Beaucoup de glaciers en crue sont aisément identifiables sur les images. La couverture par satellite va permettre d'identifier sur toute la surface du globe les glaciers en crue, ce qui permet aux glaciologues d'espérer comprendre leur distribution géographique particulière. Des images de grands glaciers prises sous un faible angle solaire et avec une couverture de neige complète montrent de légers changements de pente jusqu'ici non soupçonnés et que l'on peut interpréter, soit comme un phénomène dynamique d'écoulement ou comme des reflets de la topographie sous-glaciaire.

Les images ERTS fournissent de nouvelles données glaciologiques pour plusieurs raisons: de très grandes surfaces sont explorées de manière répétitive avec une précision suffisante pour déceler des changements très fins de coloration, les extensions minimales et maximales du couvert neigeux, des détails morphologiques infimes sous faible angle d'éclairement solaire et des changements dans la position des glaciers.

Zusammenfassung. Verwendung von ERTS-Bildern in der Gletscherforschung. Die sonnen-synchrone Umlaufbahn des ERTS-Satelliten erfasst die gesamte Erde von $81^{\circ} \mathrm{N}$. bis $8 \mathrm{r}^{\circ} \mathrm{S}$. alle 18 Tage jeweils um etwa $10^{\mathrm{h}}$ Ortszeit. Die Abtastgeräte an Bord haben seit dem Start am 23. Juli 1972 bis heute (Sommer 1974) ununterbrochen Bilder zur Erde übermittelt. Bilder aus 4 Spektralbereichen $\left(0,5^{-1,1} \mu \mathrm{m}\right)$ mit einer Bodenauflösung von etwa $100 \mathrm{~m}$ überdecken jeweils quadratische Gebiete mit $185 \mathrm{~km}$ Seitenlänge. Die ausgegebenen Bilder haben sich als sehr brauchbar für die Ermittlung gewisser Grunddaten über Gletscher erwiesen.

So lassen sich langfristige Fliessgeschwindigkeiten an der Oberfläche leicht durch Vergleich der ERTSBilder mit Karten aus früheren Aufnahmen bestimmen. Die Bilder dienten zur Messung von Geschwindigkeiten auf dem Malaspina-Glacier über eine Periode von ro Jahren, von Ausbruchsverlagerungen am Lowell-, Tenas Tikke-, Tweedsmuir-Glacier und Lednik Medvezhiy und der Geschwindigkeit am Rande des Hubbard-Glaciers. Auf den Bildern sind viele ausbrechende Gletscher ohne weiteres zu erkennen. Die Satellitenaufnahmen ermöglichen die weltweite Erkennung ausbrechender Gletscher, woraus sich eine Hilfe für das Verständnis ihrer besonderen geographischen Verteilung ergeben kann. Bilder grosser Gletscher, die bei niedrigem Sonnenstand und unter völliger Schneebedeckung aufgenommen wurden, zeigen bisher unbekannte, leichte Neigungsänderungen, die als dynamische Fliesserscheinungen oder als Spiegelbilder der subglazialen Topographie gedeutet werden können.

ERTS-Bilder vermitteln neue Gletscherdaten aus folgenden Gründen: Sehr grosse Gebiete werden wiederholt mit ausreichender Häufigkeit erfasst, so dass sie geringfügige Helligkeitswechsel, Zustände maximaler und minimaler Schneebedeckung, feinste morphologische Erscheinungen bei niedrigem Sonnenstand sowie Lageänderungen der Gletscher erkennbar machen. 
THE FIRST images taken from satellites of sufficient resolution, sequential regional coverage, and widespread availability to be quantitatively useful at a scale of individual mountain glaciers were produced by ERTS-I (Earth Resources Technological Satellite). This satellite was launched on 23 July 1972 and was still recording images of North America in the summer of 1974. The circular, sun-synchronous orbit reaches to lat. $8 \mathrm{I}^{\circ}$ at an altitude of $930 \mathrm{~km}$. Complete global coverage occurs every $18 \mathrm{~d}$; this allows repeated images of any particular point on an $18 \mathrm{~d}$ cycle. Overlap of the orbit, which increases toward the polar regions, may allow the same point to be imaged on two or more successive days in a single $18 \mathrm{~d}$ period. The operational sensor is a multi-spectral scanner (MSS) which scans in four bands: (4) $0.5^{-0.6} \mu \mathrm{m},(5) 0.6-0.7 \mu \mathrm{m},(6) 0.7-0.8 \mu \mathrm{m}$, and (7) $0.8-1 . \mathrm{I} \mu \mathrm{m}$. The bands can be combined to form various color renditions. Electronic image data are relayed to a ground station directly, or, when no station is visible to the satellite, recorded and later relayed. These data are then compiled into various photographic and digital formats and distributed to the public (NASA, r972) through the EROS Data Center, Sioux Falls, South Dakota 57 r 98.

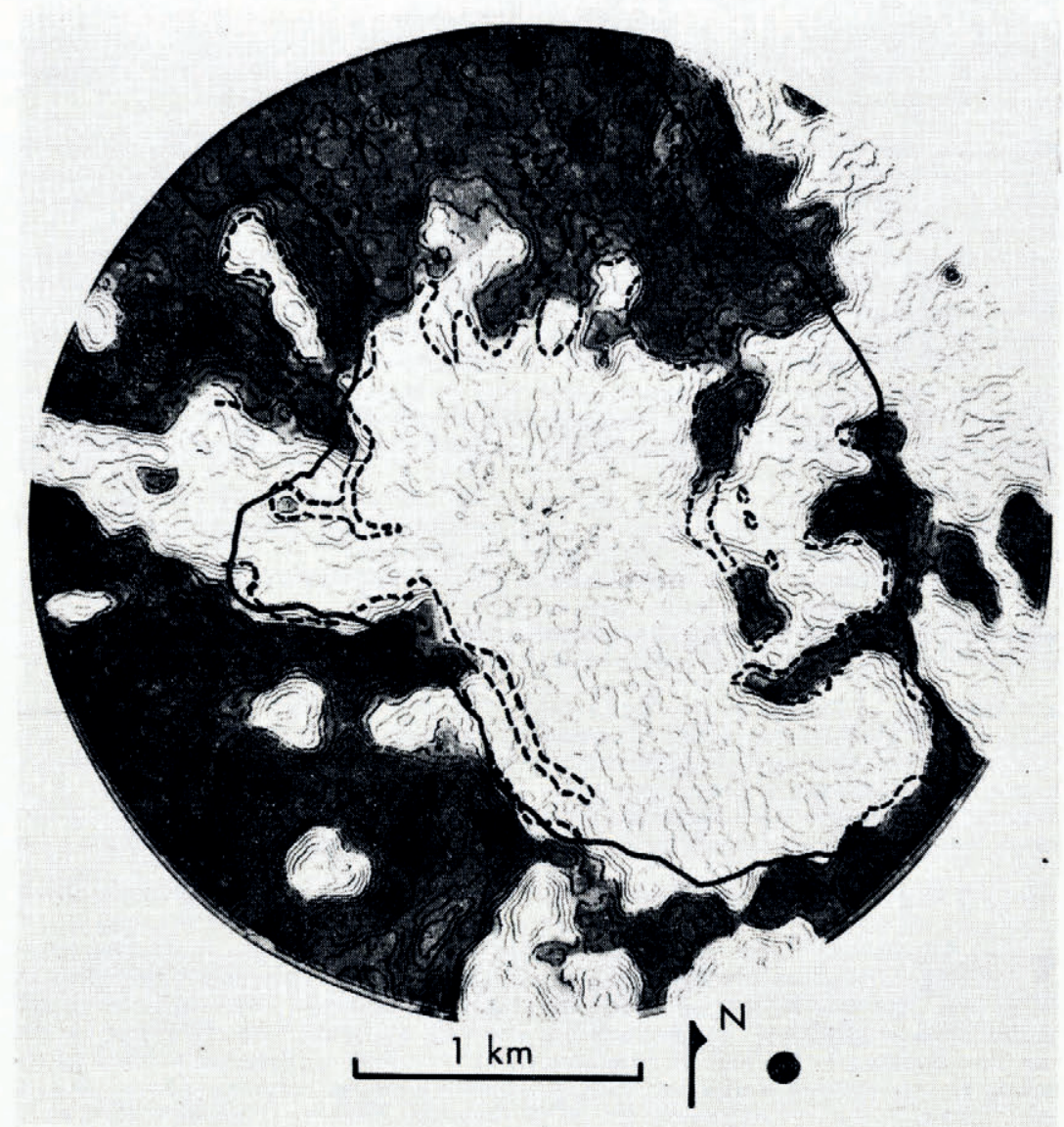

Fig. I. Density-contour scan of ERTS image of South Cascade Glacier basin. The heavy dark line is the basin outline. Areas determined to be snow free using the ERTS data are shaded. The snow line as determined from ground and aerial photography is dashed. The black dot indicates the resolution element of the scanning microscope and represents a circle $84 \mathrm{~m}$ in diameter. ERTS image $13^{3} 7^{-18} 3_{31-5}$ (II August 1973). 


\section{Resolution}

A key to the usefulness of space images is resolution. The resolution of the ERTS MSS system is generally considered to be about $100 \mathrm{~m}$, although under ideal conditions and with high contrast between objects, resolution is sometimes as high as $70 \mathrm{~m}$. Snow lines in mountainous areas are intricate, and there is often high contrast between snow and rock or vegetation, and thus snow cover provides an ideal test of resolution. The snow line is routinely mapped from ground or aerial photographs in the South Cascade Glacier basin (lat. $48^{\circ} 22^{\prime} \mathrm{N}$., long. $12 \mathrm{I}^{\circ} \mathrm{O} 3^{\prime} \mathrm{W}$.) for several dates during a typical melt season to help relate water input and outflow from the basin. This basin is approximately $6 \mathrm{~km}^{2}$ in area, and massbalance data are compiled using a $100 \mathrm{~m}$ grid - in effect, a $100 \mathrm{~m}$ resolution. Snow outlines were drawn using ERTS images for several dates and by various methods. The simplest technique is to trace the snow line visually from optically enlarged images. This method is subjective as the observer must mentally estimate a line of equal density (grey tone) or sharp gradient in density.

A more objective method is through the use of a density-contour producing microscope (scanning densitometer). Several South Cascade images were also analyzed using this equipment. Although the machine can give an objective density contour, one must subjectively select the contour that most accurately represents the snow line. A density contour scan and the contour chosen as the most representative of the snow line are shown in Figure $\mathrm{I}$. The aperture (resolution element) of the microscope used to produce these contours was $25 \mu \mathrm{m}$ which represents $84 \mathrm{~m}$ on the ground, and is shown on the enlarged product as a dot. An aperture equivalent to $42 \mathrm{~m}$ was tried, but this resulted in a very noisy scan, showing that the image resolution was exceeded. Direct comparison of the density-contour snow line with

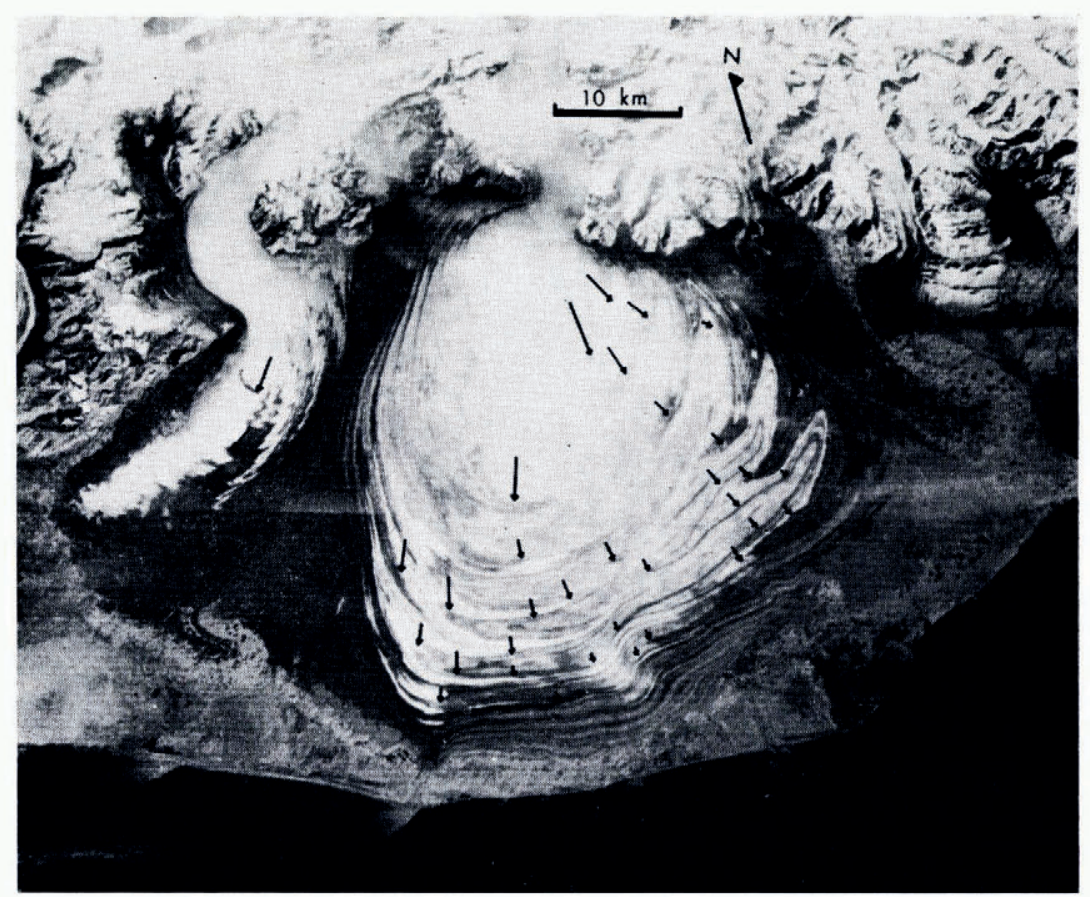

Fig. 2. Malaspina Glacier with Io year velocity vectors superimposed. Vectors were determined by direct comparison of an ERTS image with a previous map compiled from aerial photographs. ERTS image 1420-20102-6 (16 September I973). 


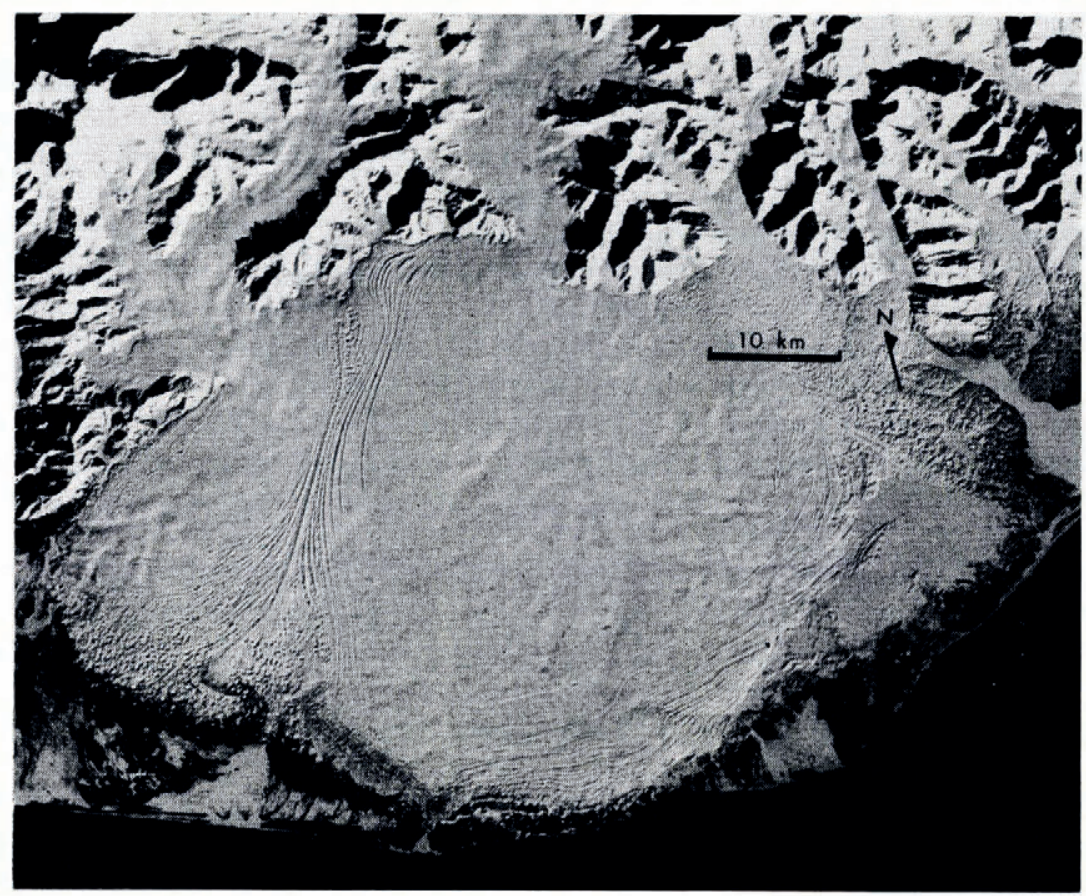

Fig. 3. Malaspina Glacier with new snow and a sun angle of $14^{\circ}$ above the horizon. ERTS image 1204-20120-6 (I2 February 1973).

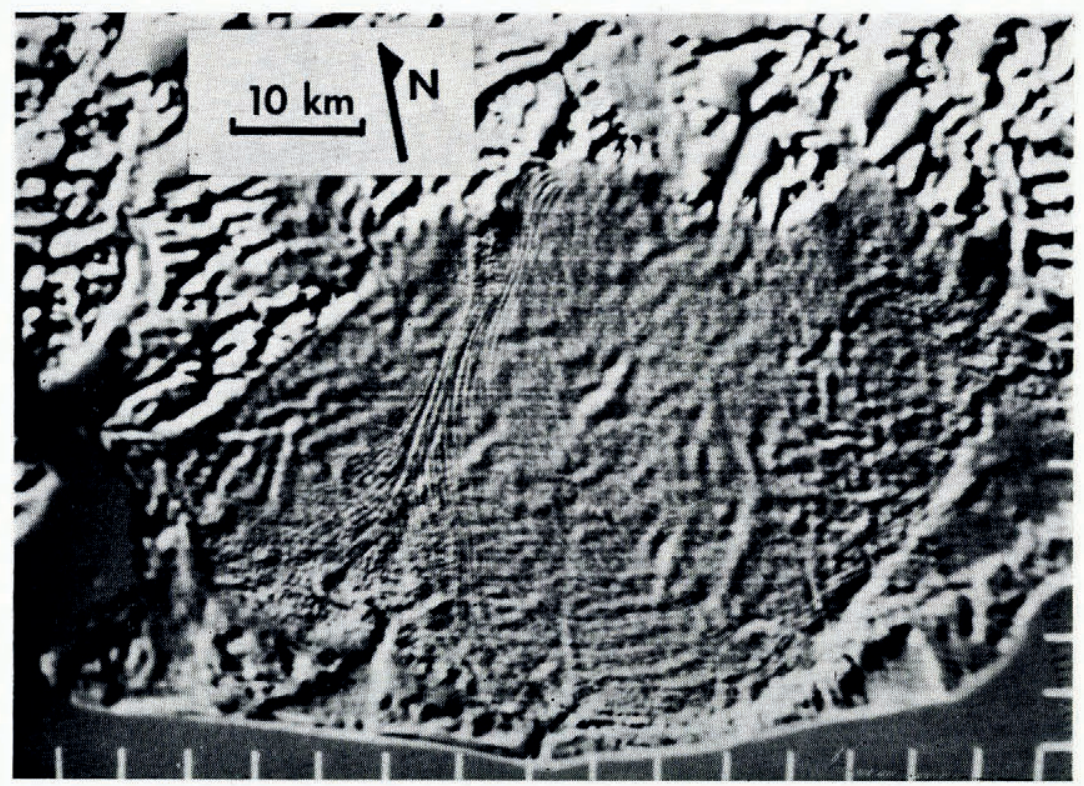

Fig. 4. Enhancement of February ERTS image of Malaspina Glacier. A positive superimposed with its negative, but slightly offset, with greatly enhanced contrast, highlights slight tonal variations. ERTS image 1204-20120 (I2 February 1973). 
the snow line drawn from ground and aerial photography is also shown in Figure $\mathrm{I}$. Generally the snow lines produced from the space image are smoother, as is to be expected, but values for the final snow-cover area agree well. Increased resolution could be obtained with the use of digitized images, but this requires more sophisticated equipment and more costly and difficult analysis.

Thus, we can state that in a basin where a $100 \mathrm{~m}$ ( $\mathrm{I} \mathrm{ha)} \mathrm{resolution} \mathrm{is} \mathrm{adequate,} \mathrm{useful}$ snow-line or accumulation area data can be obtained from ERTS. Of course, conventional aerial photography can offer much better resolution. The advantages of ERTS are: (I) a virtually distortion-free orthographic view is produced, which simplifies data transfer to maps, (2) due to the large areal coverage of ERTS, many glaciers or large glaciers can be analyzed, and (3) because of the four channels, various methods of color enhancement or multi-spectral analysis can be used.

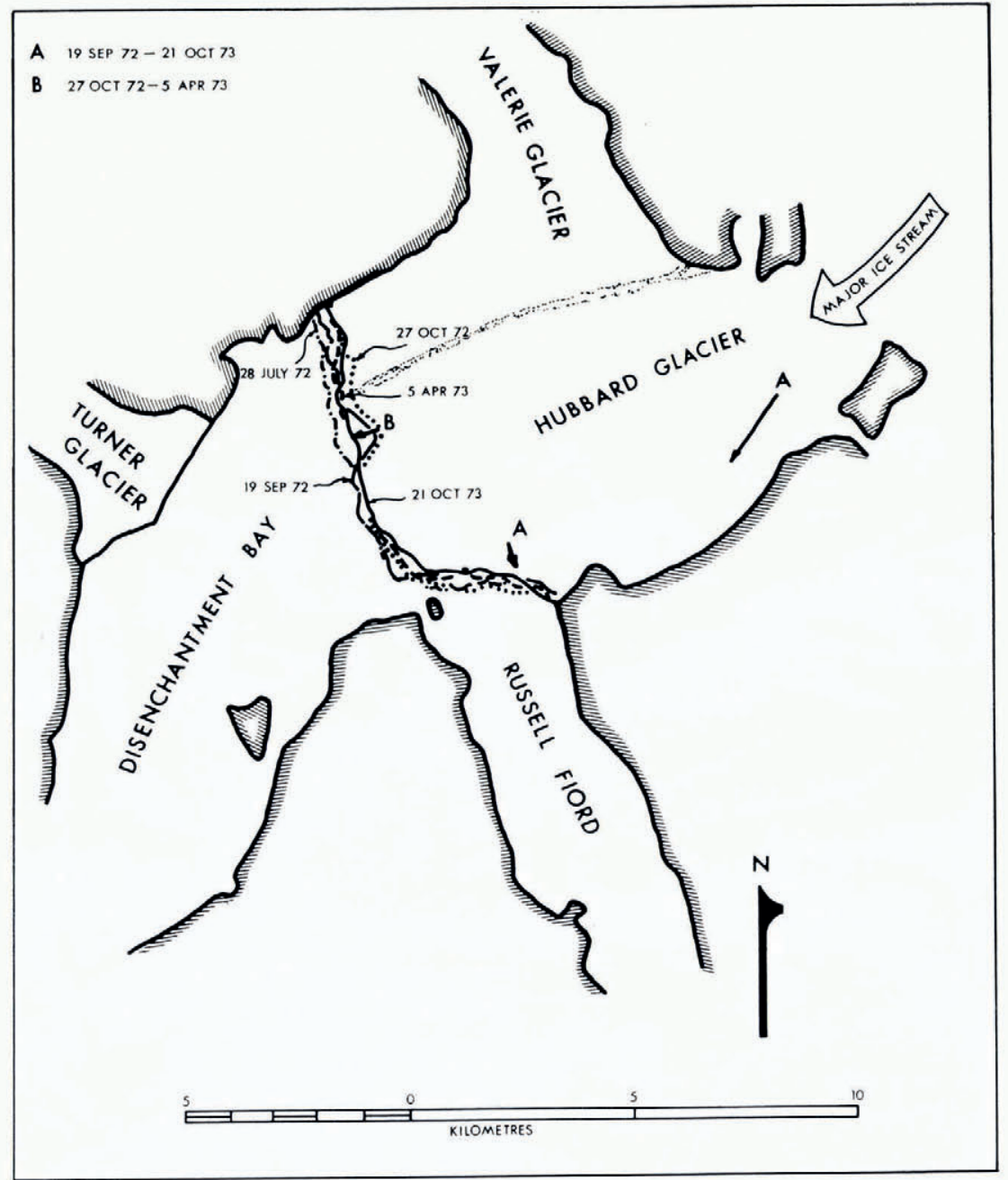

Fig. 5. Terminus positions of the Hubbard Glacier as determined from several ERTS images. Terminus displacement vector $\ddot{B}$ is from 27 October 1972 to 5 April 1973 and surface velocity vectors A from 19 September 1972 to 21 October 1973. 


\section{Glacier movement}

The regional coverage that ERTS imagery provides is advantageous for other reasons. The Malaspina Glacier (lat. $60^{\circ} \mathrm{oo}^{\prime} \mathrm{N}$., long. $140^{\circ} 4 \mathrm{o}^{\prime} \mathrm{W}$.) is about $50 \mathrm{~km}$ across. Aerial photographs of the glacier taken in 1962 were mosaicked together and the folded moraine positions meticulously plotted by Austin Post. ERTS images from 1972 were enlarged and compared directly to the 1962 map, a very quick and relatively easy task. The resulting io year velocity vectors are shown superimposed on a slightly more recent 1973 image (Fig. 2).

\section{SURFACE AND BEDROCK FEATURES}

An image taken of the Malaspina Glacier in February 1973 , with a sun elevation of $14{ }^{\circ}$ and a uniformly reflecting surface of new snow, shows very slight slope changes as subtle tonal variations (Fig. 3). These tonal variations can be accentuated by first superimposing a negative and positive of the same image, then offsetting the images slightly and subsequently enhancing the contrast. This was done on an electronic console (Evans and Serebreny, 1973), and the results are shown in Figure 4. A number of linear features are apparent which have no obvious relation to moraines or other known surface features.

The thickness of the central part of the Malaspina Glacier ranges from 500 to I ooo $\mathrm{m}$ (Allen and Smith, 1953) and surface velocities are on the order of 2 to $300 \mathrm{~m} /$ year as determined by a map and ERTS image comparison. The wavy patterns and lineaments seen in the enhanced ERTS version are only surface features, but may be a reflection of the basal features, and perhaps can be interpreted as subglacial stream beds or differential erosion of geologic structures or formations. Thus they may relate to bedrock roughness elements, and hence subtly reflect the subglacial topographic relief.

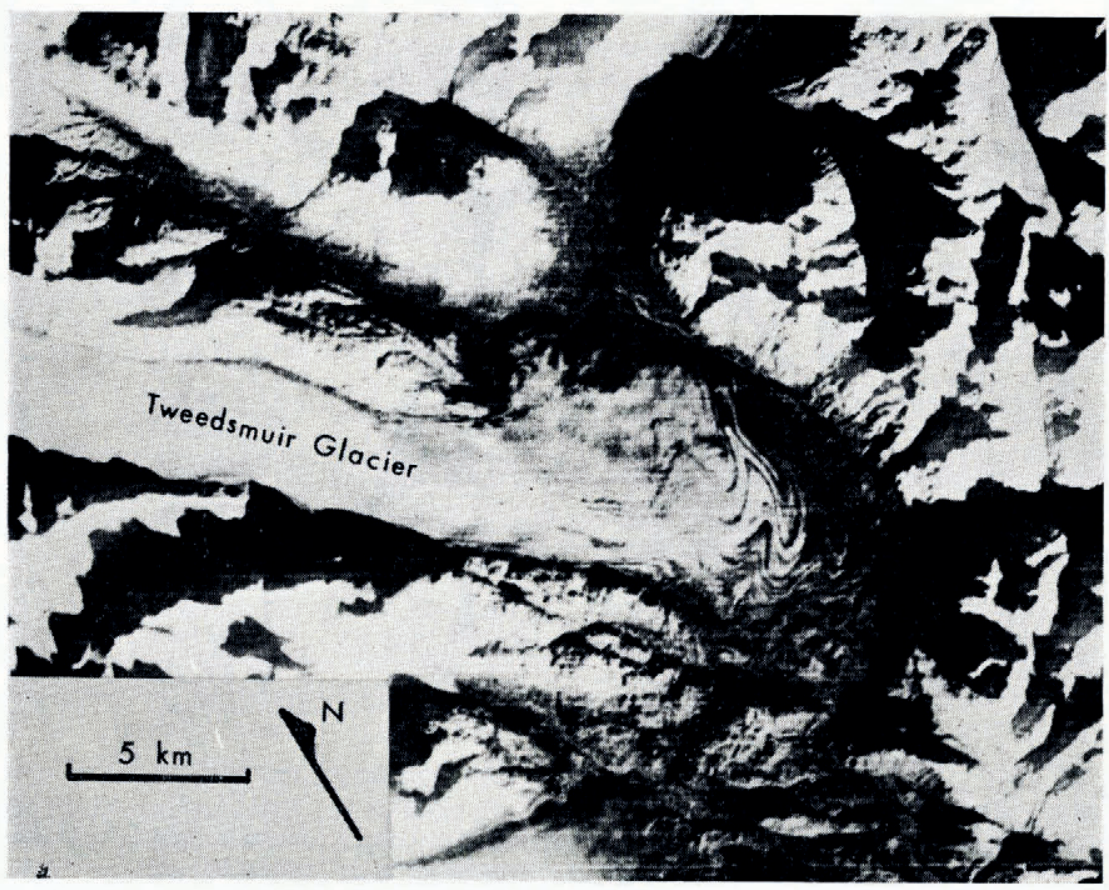

Fig. 6. ERTS image of Tweedsmuir Glacier. ERTS image 1471-19520 (6 November 1973). 


\section{Terminus changes}

Successive ERTS images can be used to determine short-term changes in terminus position and shape. The Hubbard Glacier (lat. $60^{\circ} 05^{\prime}$ N., long. $139^{\circ} 25^{\prime}$ W.), a tidal glacier in south-east Alaska, is about $100 \mathrm{~km}$ long and has recently attracted attention because of its slow advance across the mouth of the Russell Fiord. If the $200 \mathrm{~km}^{2}$ fiord were blocked, it would become a fresh-water lake which would either have an outlet at the opposite end or might periodically burst out through Hubbard Glacier (Post and Mayo, I97I). The glacier has been slowly advancing since 1895 , and by 1970 had come within $400 \mathrm{~m}$ of closing the fiord. Figure 5 shows terminus positions for several dates as determined from ERTS images in 1972 and 1973 , and indicates that the advance has at least temporarily ended. A minimum distance of ice advance between 27 October 1972 and 5 April 1973 was $600 \mathrm{~m}$, as an embayment in the terminus was closed in that time. Surface displacements of 600 and $1800 \mathrm{~m}$ from 19 September 1972 to 2 I October 1973 were also measured directly from the ERTS images.

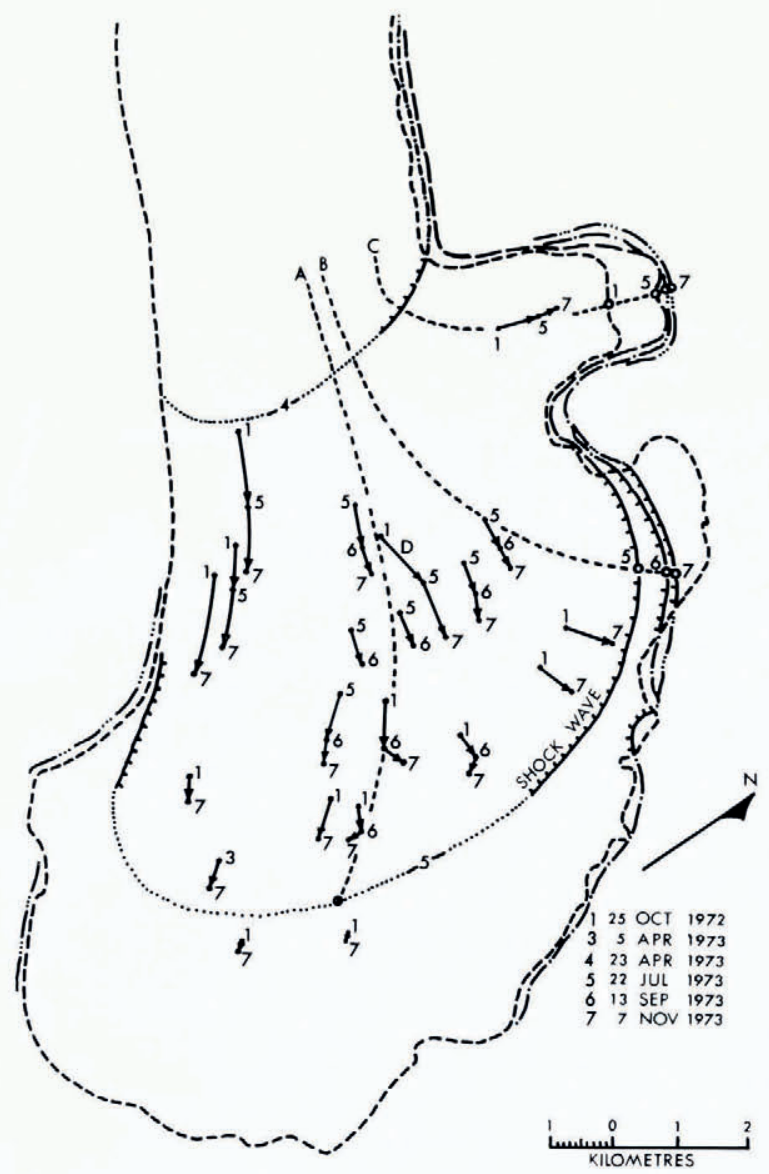

Fig. 7. Tweedsmuir Glacier. Arrows are surface velocity vectors; numbers by dots give the time interval. Shock-wave velocities were determined along lines $A, B$ and $C$. All information here taken solely from ERTS images by L. R. Mayo, U.S. Geological Survey. 


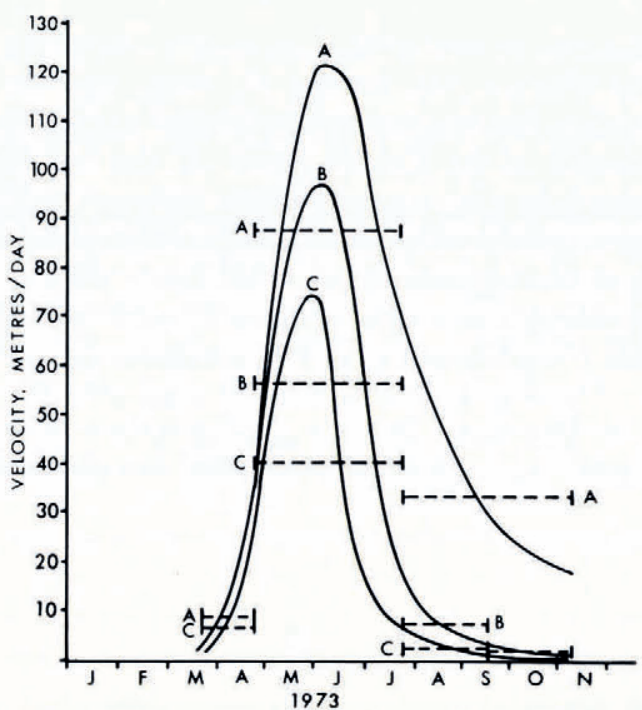

Fig. 8. Shock-wave velocities along three longitudinal lines of Tweedsmuir Glacier during surge. Dashed lines are measured values, solid lines are inferred. Refer to Figure 7 for locations.

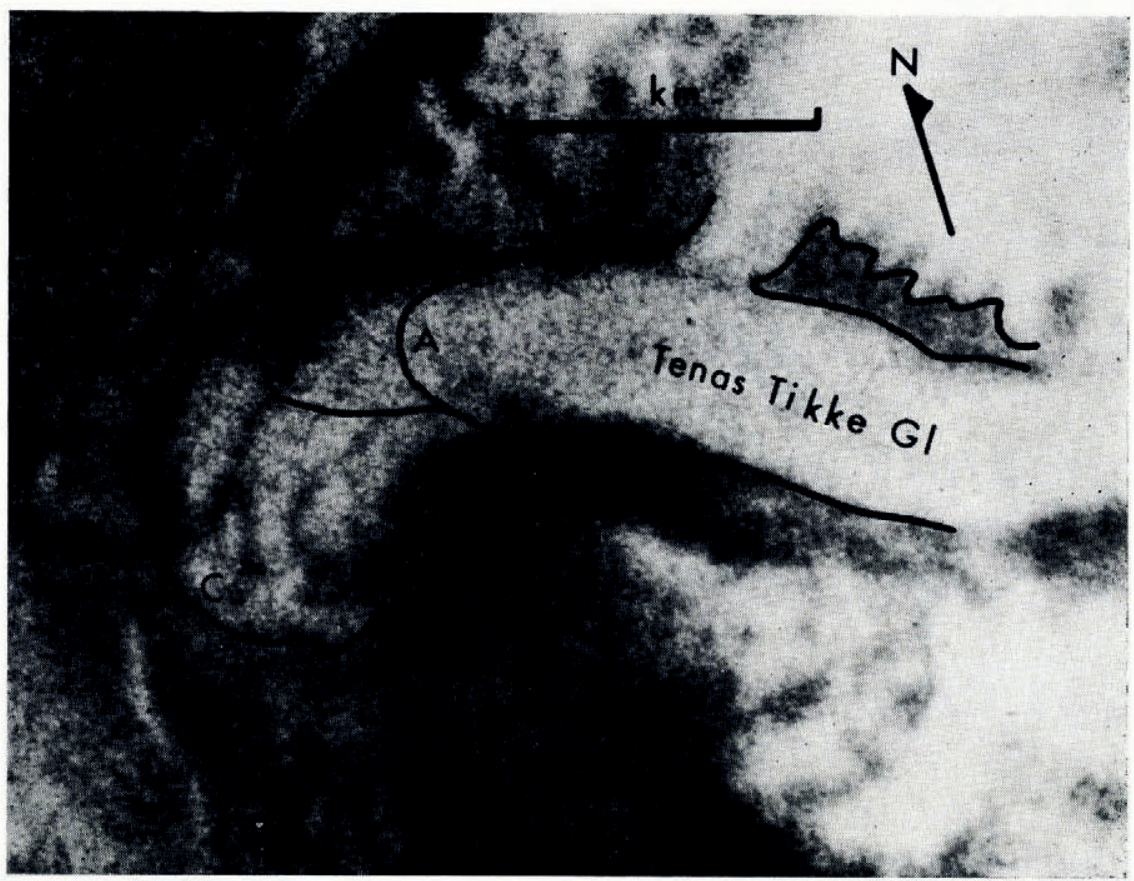

Fig. 9: A spectacular surge of the Tenas Tikke Glacier advanced the terminus $1 \mathrm{~km}$ before September $1972(B)$ and an additional $2 \mathrm{~km}$ by September $1973(C) .(A)$ is the pre-surge position of the terminus of the glacier. ERTS image $1416-19480$ (12 September 1973). 


\section{Glacier surges}

The resolution and period of ERTS should allow useful time-lapse data to be obtained before, during, and after glacier surges. The Tweedsmuir Glacier, (Fig. 6) (lat. $59^{\circ} 40^{\prime}$ N., long. $138^{\circ} 10^{\prime} \mathrm{W}$.), was noted to be surging during an aerial photographic flight in September 1973. Analysis of several ERTS images taken from October 1972 through November 1973 was undertaken by L. R. Mayo; these data are presented in Figures 7 and 8. The technique used for this analysis was to compare sequential photographic enlargements; Figure 8 shows measured and inferred shock-wave velocities in the terminal region. The inferred velocities

\section{LOWELL GLACIER}
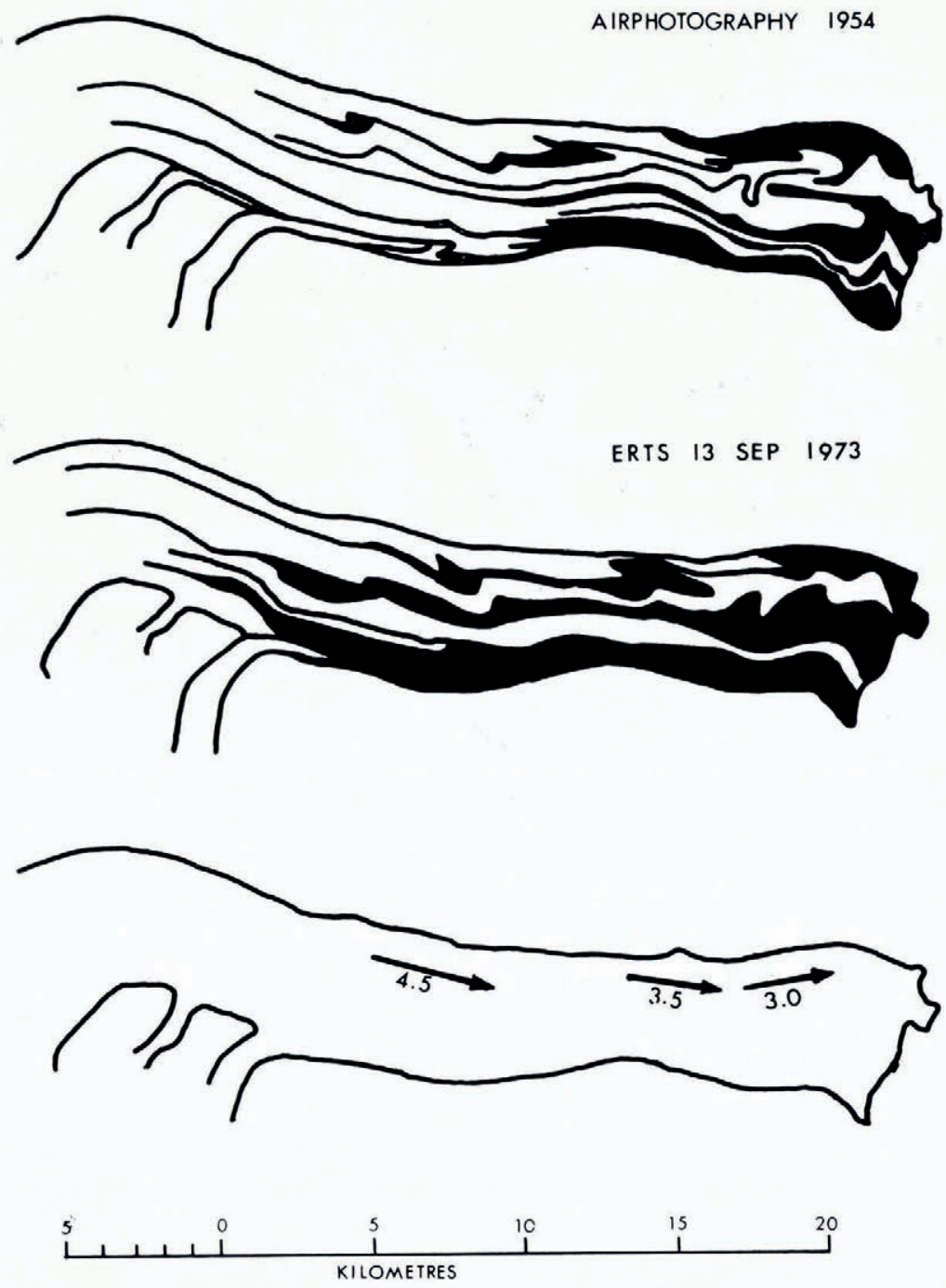

Fig. 1o. Surge displacements measured on the Lowell Glacier by comparison of ERTS images to previously drawn maps, which were compiled from aerial photographs. 
were determined by drawing smooth curves that pass through the average displacement rates. The shock wave, near the center of the glacier, advanced at an average rate of $88 \mathrm{~m} / \mathrm{d}$ from 23 April to 22 July 1972, at least an order of magnitude faster than the actual ice velocity. Although actual crevasses can rarely be seen on ERTS images, a darkening of the surface indicates a greater number of crevasses. During the surge the darkening proceeded up glacier $40 \mathrm{~km}$ in less than $\mathrm{I} 8 \mathrm{o} \mathrm{d}$, at a rate of some $220 \mathrm{~m} / \mathrm{d}$. This and the location of the first noticeable shock wave in March and April indicate the surge began somewhere between 40 and $55 \mathrm{~km}$ from the head of the $70 \mathrm{~km}$ long glacier.

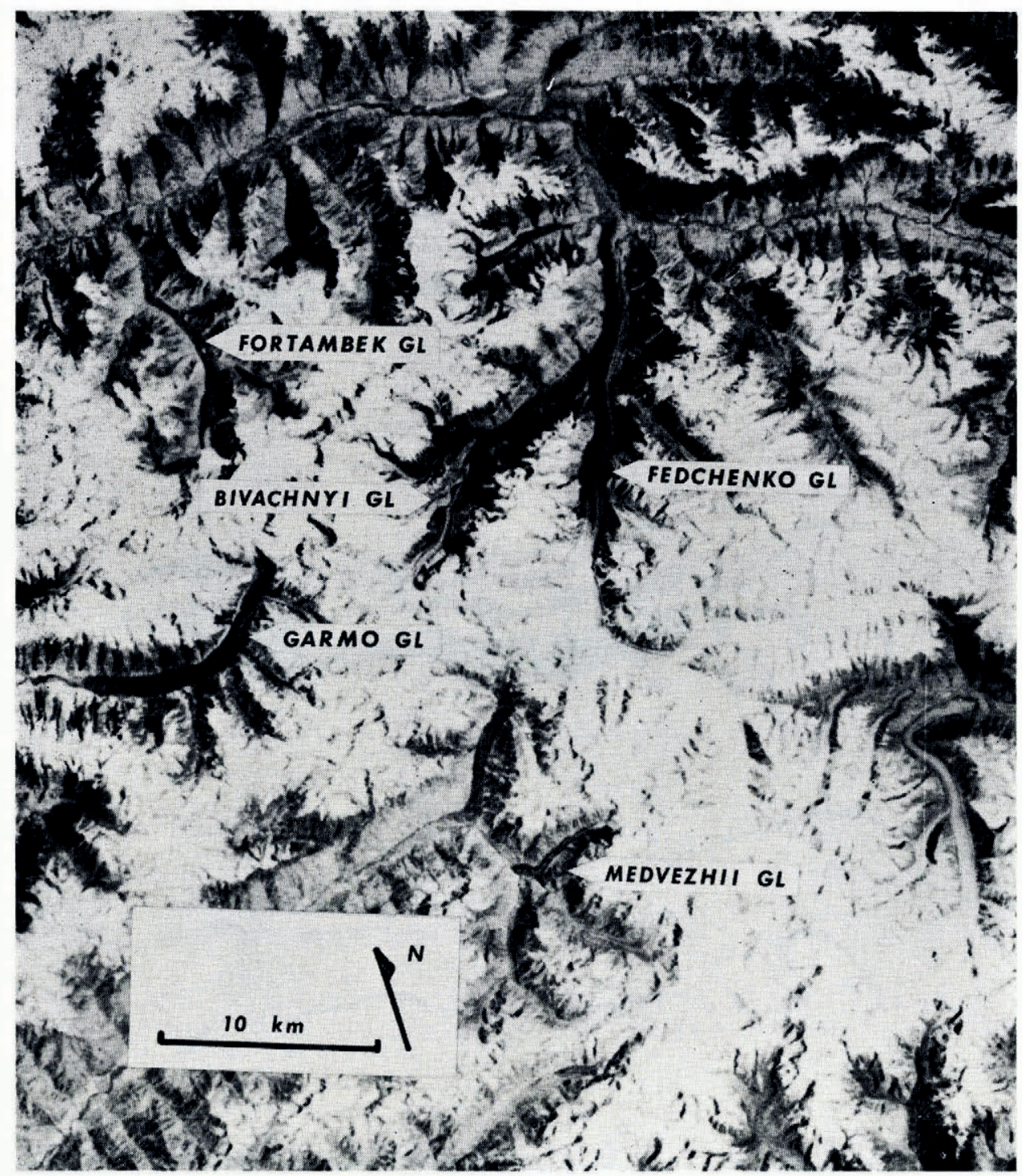

Fig. II. ERTS image of Pamirs of Soviet Union. This image shows Lednik Medvezhiy after just completing a surge. Six surge-type and 16 glaciers with indistinct surge features have been identified on this image. ERTS image $1354^{-05224-7}$ (12 July 1973). 
Another surge, that of the Tenas Tikke Glacier (lat. $59^{\circ} \mathrm{Io}^{\prime} \mathrm{N}$., long. $137^{\circ} \mathrm{oo} \mathrm{o}^{\prime} \mathrm{W}$.), was first noticed in an aerial photographic flight in September 1972. At that time it was supposed that this surge was just about finished after an advance of about $\mathrm{I} \mathrm{km}$ from a previous length of $10 \mathrm{~km}$. The 1973 aerial photographic flight showed the Tenas Tikke to have continued its advance an unexpected $2 \mathrm{~km}$ farther. At approximately the same time, ERTS imagery of the area was produced and the additional advance was very apparent (Fig. 9).

Another example in which surge displacements were easily determined through the use of ERTS data is that of the Lowell Glacier (lat. $60^{\circ} 18^{\prime}$ N., long. $13^{8^{\circ}} 5^{I^{\prime}}$ W.). The Lowell Glacier surged in 1968-70. A map of the medial-moraine pattern had been made before the surge from a mosaic of aerial photographs. A new map made directly from ERTS enlargements and compared to the earlier map allowed displacement vectors to be determined (Fig. Io).

The near-global coverage capability of ERTS is another great advantage. Figure I I is a part of an image taken 12 July 1973 over the Pamirs of the Soviet Union (image center lat. $38^{\circ} 57^{\prime}$ N., long. $72^{\circ}$ o6 $6^{\prime}$ W.) and is a good example of this capability. In this image Lednik Medvezhiy is nearing the completion of a surge and a small surge-dammed lake is visible. Six other surging-type glaciers have been identified in this image including Ledniki Fortambek, Garmo, and Bivachnyy. The Bivachnyy shows characteristic moraine loops, and based on comparisons of similar glaciers in Alaska such as the Black Rapids Glacier (lat. $63^{\circ} 30^{\prime} \mathrm{N}$., long. $146^{\circ} 30^{\prime} \mathrm{W}$.) it is predicted that the Bivachnyy will surge within a few years with an ice displacement of about $2 \mathrm{~km}$. At least 16 other glaciers on this image show surging characteristics.

\section{Conclusions}

ERTS images offer several advantages over other available methods for observing glaciers. A regional view is offered and large glaciers and ice caps that previously required tedious compilation of photographs into mosaics can now be seen on one frame. Features that are very subtle, but large, are often lost in the process of constructing mosaics. Furthermore, ERTS images are taken at times when aerial photography is not usually taken; for instance, under conditions of complete snow cover and low sun angle; these two factors often accent subtle regional topographic features. The repetitive coverage that ERTS offers is also useful in monitoring dynamic phenomena, the only requirement being that the changes observed exceed the resolution of the ERTS data. Finally, the near-global coverage that the ERTS system provides has obvious advantages.

The examples used in this paper illustrate only some of what has been done. To date the volume of data that ERTS has produced is much greater than has been utilized. Problems of data acquisition and distribution presently exist, but improvement is expected.

A major step in the data analysis not discussed here, but presently being undertaken, is computer processing of digital tapes. Images are available in the form of four reels of magnetic tape per set of four bands of one image. The computer-compatible tape format for ERTS images offers the advantages of maximum resolution and the greater analytical possibilities from computer processing of data.

\section{REFERENCES}

Allen, C. R., and Smith, G. I. 1953. Seismic and gravity investigations on the Malaspina Glacier, Alaska. Transactions. American Geophysical Union, Vol. 34, No. 5, p. 755-6o.

Evans, W. E., and Serebreny, S. M. 1973. Analysis of ERTS imagery using special electronic viewing/measuring equipment. (In Freden, S. C., and others, comp. and ed. Symposium on significant results obtained from the Earth Resources Technology Satellite-1. Vol. 2. The proceedings of a symposium held by Goddard Space Flight Center at New Carrollton, Maryland, on March 5-9, 1973. Compiled and edited by S. C. Freden, E. P. Mercanti and M. A. Becker. Washington, D.C., Scientific and Technical Information Office, National Aeronautics and Space Administration, p. 12 1 I-18. (NASA SP-327.))

NASA. I972. Data users handbook. NASA Goddard Space Flight Center Document 7 I SD 4249.

Post, A. S., and Mayo, L. R. 1971. Glacier dammed lakes and outburst floods in Alaska. Washington, D.C., U.S. Geological Sarvey. (Hydrologic Investigations Atlas HA-455.) 


\section{DISCUSSION}

C. W. M. Swithinbank: ERTS coverage is not world-wide. Unfortunately neither ERTS-I nor ERTS-B are programmed for even one-time coverage of all the land between latitudes $8 \mathrm{I}^{\circ} \mathrm{N}$. and $8 \mathrm{I}^{\circ} \mathrm{S}$.

R. S. Williams, JR: Over the two years of global data acquisition by ERTS-I the first priority was given to data acquisition by the 322 ERTS-I principal investigators under contract to NASA. After their needs were satisfied NASA endeavored to provide one-time coverage of the entire world. However, certain areas of the world which are important in the raising of crops, such as China and Russia turned out to have higher priority, and therefore received more frequent coverage, than other areas. Acquisition of data imagery for these areas on a repetitive basis precluded coverage of other parts of the world which had no such coverage priority. It is interesting to note that this data-acquisition program was created late in the ERTS-I program to satisfy an internal U.S. Government (NASA, Department of Agriculture, and other agencies) project. This project, which includes discrete cooperation with other nations, is called LACIP (Large Area Crop Inventory Program). [Note added after Symposium: The LACIP is now included in an ERTS-B program (in addition to the 93 approved experiments) as one of several "ASVT" (application systems verification tests). It is estimated that over $70 \%$ of the total tape-recorder capacity on ERTS-B will therefore be devoted to the repetitive global crop inventories.]

It is hoped that NASA, with ERTS-B, will again return to the original lofty and worthy objectives of ERTS-I and also to try to achieve at least one-time coverage of all land areas of the world, including the Antarctic. This is particularly important because the ERTS system represents the most important contribution yet made to all the peoples of the world from space technology. It is the only space project which at least began as a totally civilian, non-military endeavour.

W. F. BudD: Have you been able to use overlapping ERTS images in stereo to obtain elevation contours?

R. M. KRimmel: We have not used this in our own studies, it has been attempted by others though.

J. MacDowall: Stereo can be seen over the Rocky Mountains, and false stereo has been noted by $\mathrm{E}$. Langham as an easy way to observe differential sea-ice movement.

Williams: NASA applies 14 corrections to ERTS (MSS) imagery, thereby producing a distorted stereo model, unusable for topographic mapping. In Iceland, where significant sidelap of adjacent images (successive days) is the case, good stereo can be achieved. However, relative height measurements taken on Herðubreið, a table mountain in north-east Iceland which stands $\mathrm{I}$ ooo $\mathrm{m}$ above the surrounding terrain, permit Io contours to be drawn or one each $100 \mathrm{~m}$. This appears to be the potential capability of ERTS-I. 